\title{
Immunodeficiency due to CD25 deficiency
}

INSERM

\section{Source}

INSERM. (1999). Orphanet: an online rare disease and orphan drug data base.

Immunodeficiency due to CD25 deficiency. ORPHA:169100

Immunodeficiency due to CD25 deficiency is a rare, genetic, primary immunodeficiency due to a defect in adaptive immunity disorder characterized by severe immunodeficiency, presenting with profound susceptibility to viral, fungal and bacterial infections due to impaired CD25-mediated T-regulatory cell function, in association with severe autoimmune disease, such as alopecia universalis, erythrodermia, and autoimmune thyroiditis and enteropathy. 